\title{
In vitro axillary shoot regeneration from cotyledonary node of Bishop's weed (Trachyspermum ammi L.)
}

1, Karamanoglu Mehmetbey University, Science Faculty, Department of Biology, Karaman, Turkey

${ }^{2}$ Sivas Science and Technology University, Agricultural Sciences and Technology Faculty, Dept. of Plant

Protection, Sivas, Turkey

*mshazim@gmail.com, 19asumankoca70@gmail.com

Received : 29.08.2021

Accepted : 01.10.0021

Online : : 16.10 .0021

\section{Bishop otunun (Trachyspermum ammi L.) kotiledon boğum eksplantından in vitro aksil sürgün rejenerasyonu}

\begin{abstract}
Bishop's seed (Trachyspermum ammi L.) is a vital neutraceutial plant used as spice and also used as medicinal plant for curing different ailments and diseases of humans and animals. The study presents the in vitro regeneration of Bishop's seed using cotyledonary node explant taken from in vitro germinated seeds. All mediums used in this study were comprised of MS (0.44\%) medium having 3.0\% sucrose and $0.65 \%$ agar with $\mathrm{pH}$ of 5.8. Explants were inoculated on MS medium enriched with $0.10-1.60 \mathrm{mg} / \mathrm{L}$ Thidiazuron (TDZ) alone or in combination with $0.10 \mathrm{mg} / \mathrm{L}$ IBA (Indole3-butyric acid) for seven weeks under 16/8 light photoperiod provided with cool-white fluorescent lamps. Thereafter, explants were sucultured on MS medium without any plant growth regulators (PGRs) for five weeks more under similar culture conditions. Results revealed $100 \%$ shoot regeneration frequency with $42.85-100.00 \%$. The shoot count and shoot length ranged 3.43-19.40 and 1.04-2.74 cm respectively. The highest shoot count (19.40) and shoot length $(2.74 \mathrm{~cm})$ were observed on MS medium enriched with $0.20 \mathrm{mg} / \mathrm{L} \mathrm{TDZ}$ and $0.20 \mathrm{mg} / \mathrm{L}$ TDZ+0.10 mg/L IBA respectively. Relatively low rooting was recorded on IBA containing medium with low adaptation percentage of plantlets in pots containing peat moss.
\end{abstract}

Key words: Bishop's weed, cotyledonary node, in vitro, thidiazuron

\begin{abstract}
Özet: Bishop otu (Trachyspermum ammi L.) çok önemli baharat olarak kullanılan nutrasötik bitki olup, aynı zamanda insan ve hayvanların farklı rahatsızlık ve hastalıklarını tedavi için kullanılan tıbbi bitkidir. Bu çalışmada Bishop otunun in vitro çimlenmiş fidelerden elde edilen kotiledon boğum eksplantlar kullanılarak in vitro çoğaltım yapılmıştır. Tüm çalışmalarda \% $0.44 \% \mathrm{MS}$, $\% 3.0$ sukroz ve $\% 0.65$ agar ile 5,8 pH içeren besi ortamı kullanılmıştır. Eksplantlar 0.10-1.60 mg/L Thidiazuron (TDZ) veya 0.10-1.60 mg/L TDZ+ 0,1 mg/L Indole-3-butyric acid (IBA) içeren besi oratmlarında kültüre alınarak yedi hafta boyunca soğuk beyaz floresan lambalar ile desteklenmiş 16/8 saat 1şık fotoperyotında bekletilmiştir. Daha sonra eksplantlar her hangi hormone içeremeyen MS besi ortamına alt kültüre alınarak benzer koşullarda beş hafta boyunca bekletilmiştir. Sürgün rejenerasyon yüzdesi 100 olurken kallus rejenerasyon yüzdesi ise $\% 42,85-100,00 \%$ arasında kaydedilmiştir. Sürgün sayısı ve sürgün uzunluğu ise sırasıyla 3,43-19,40 ve 1,04-2,74 cm olarak kaydedilmiştir. En fazla sürgün sayısı $(19,40)$ ve sürgün uzunluğu $(2,74 \mathrm{~cm})$ sırasiyla $0,20 \mathrm{mg} / \mathrm{L}$ TDZ ve $0,20 \mathrm{mg} / \mathrm{L}$ TDZ $+0,10 \mathrm{mg} / \mathrm{L}$ IBA içeren ortamında elde edilmiştir. Genel olarak IBA içeren ortamlarında düşük oranda köklendirme kaydedilirken, saksılarda aktarıldığında da düşük oranda adaptasyon sağlanmıştır.
\end{abstract}

Anahtar Kelimeler: Bishop otu, in vitro, kotiledon boğum, tidiazuron

Citation: Koca A, Aasım M (2021). In vitro Axillary shoot regeneration from cotyledonary node of Bishop's weed (Trachyspermum ammi L.). Anatolian Journal of Botany 5(2): 134-137.

\section{Introduction}

Bishop's seed (Trachyspermum ammi L.) with common name of Ajowan, Ajwain, Carom or Ethopian cumin (Ashraf and Orooj, 2006) is one of the significant neutraceutial spice and medicinal shrub of Apiaceae or Umbelliferae family (Jeet et al., 2012). It is widely cultivated herb mainly on saline soils of arid and semi-arid regions of Central, South and West Asia (Moosavi et al., 2015). The plant is normally tall $(60-90 \mathrm{~cm})$ having branched structure. The flowers bloom from month of July upto September and bear small sized fruit having relatively bitter pungent taste (Sharifi- Rada et al., 2013; Koca and Aasim, 2015). The oil of seeds contain essential oils having thymol as major component (Ashraf and Orooj, 2006; Bairwa et al., 2012; Moosavi et al., 2015) and used for treating diseases and disorders like anti-inflammatory (Thangam and Dhananjayan, 2003), antifilarial (Mathew et al., 2008), antilithiasis (Ramaswamy et al., 2010), bronchitis (Singh et al., 2003), digestive stimulant (Platel and Srinivasan, 2001), and stomach disorders (Jain et al., 2011). Bishop's weed is used as aflatoxin and detoxificant in perfumery and preservative in foods (Velazhahan et al., 2010), nematicide, (Kwon et al., 2007) and fungicide (Ashraf and Orooj, 2006).

Medicinal plants are highly significant for humans due to containing wide array of bioactive compounds used in different areas. These medicinal plants are gaining popularity in recent years and have been used as raw or in processed form in both traditional and modern pharmaceutical industry (Niazian et al., 2017a). The application and safe usage of organic materials in pharmaceutical industries replacing synthetic materials enhance the significance of medicinal plants (Moghaddam et al., 2015). Some of these medicinal plants also used as spice, flavor and perfume industries, which enhance the economic importance of such medicinal plants. However, 
the major issue of such medicinal plants is relatively low production with quality issues (Nomani et al., 2021). In order to cope the demand with high quality compounds, biotechnologiccal techniques have been employed (Tripathi and Tripathi, 2003; Nomani et al., 2021). Among these techniques, plant tissue culture is major and these techniques are the most effective for the manipulation of significant seccondary metabolites. In recent years, in vitro propagation of Bishop's weed have been developed for callus induction, somatic embryogenesis, direct or indirect shoot induction (Koca and Aasim 2015; Niazian et al 2017b; Teymourian et al., 2017; Nomani et al., 2021). However, there is always need of new in vitro regeneration protocols for medicinal plants. This study presents the response of cotyledonary nodes explant cultured on mediums enriched with TDZ-IBA for in vitro shoot proliferation of Bishop's weed.

\section{Materials and Method}

The seeds of Bishop's weed were purchased from Pakistan and seeds were placed in water in order to remove floated seeds followed by surface sterilization process reported by Koca and Aasim (2015). Surface sterilized seeds were inoculated on MS (Murashige and Skoog, 1962) medium without any PGRs for germination. Cotyledonary node explants used in this study were isolated from two weeks old in vitro germinated seedlings under sterile conditions. The isolated explants were transferred immediately to MS medium enriched with variable concentrations $(0.10,0.20$, $0.40,0.80$ and $1.60 \mathrm{mg} / \mathrm{L}$ ) of Thidiazuron (TDZ) used alone or with combination of $0.10 \mathrm{mg} / \mathrm{L}$ of Indole-3-butyric acid (IBA). The explants were initially cultured for seven weeks followed by subculture to MS medium without TDZ-IBA for five more weeks. The medium used in this study for in vitro regeneration and rooting medium was prepared by adding $0.44 \%$ MS medium (Duchefa), $3.0 \%$ sucrose (Duchefa), $0.65 \%$ agar (Duchefa) followed by adjusting the $\mathrm{pH}$ between 5.6-5.8. All cultures (regeneration and rooting) were incubated in the growth room equipped with coolwhite fluorescent lamps for 16/8-h (light/dark) photoperiod and temperature of $24^{\circ} \pm 1^{\circ} \mathrm{C}$.

For rooting, healthy and normal shoots (not showing hyperhydricity) were used for in vitro rooting. Shoots were isolated under sterile conditions followed by immidiate transfer to MS rooting medium provided with $0.2,0.4,0.60$, 0.80 and $1.0 \mathrm{mg} / \mathrm{L} \mathrm{IBA}$ for three weeks. In vitro rooted plantlets were transferred to pots containg peat moss. The pots were wrapped with polyethylene bags for moisture conservation and placed in the growth room at $23 \pm 1{ }^{\circ} \mathrm{C}$. After one week, holes were made in the bags for 3-4 days followed by complete opening of pots and exposed to growth room conditions.

The experiment was carried out in three replication with seven explants per replication having 10 different PGRs type and concentration. The data regarding shoot induction frequency $(\%)$, callus induction frequency $(\%)$, shoot counts and shoot length $(\mathrm{cm})$ were taken after twelve weeks of culture and analysis of variance (ANOVA) was done using SPSS 20.00 for Windows. Post hoc tests using Duncan's multiple range test (DMRT) was used for comparing means difference among PGRs treatments. Prior to statistical analysis, data was transformed into Arcsine square root transformation (Snedecor and Cochran, 1967).

\section{Results and Discussion}

Callus induction and shoot induction from cotyledonary node explant started simultaneously within two weeks of culture irrespective of PGRs type, concentration and combination. However, extensive callus induction was observed after four weeks of culture (Fig 1a) alongwith multiple shoot induction. After seven weeks of culture (Fig 1b), explants were sub-cultured to MS medium devoid of PGRs for next five weeks for shoot proliferation (Fig 1c). After twelve weeks of total culture, data regarding callus induction frequency (\%), shoot induction frequency (\%), shoot counts and shoot length $(\mathrm{cm})$ were recorded. Shoot induction frequency (\%) was recorded $100 \%$ and hence not subjected to statistical analysis. On the other hand, callus induction frequency $(p<0.01)$, shoot counts $(p<0.05)$ and shoot length $(p<0.01)$ were statistically significant to different concentration of TDZ-IBA.

Table 1. Impact of TDZ-IBA concentration on callus induction (\%) from cotyledonay node explant of T. ammi

\begin{tabular}{|c|c|c|c|}
\hline $\begin{array}{c}\text { TDZ } \\
(\mathbf{m g} / \mathbf{L})\end{array}$ & $\begin{array}{c}\text { Callus } \\
\text { Regeneration } \\
\text { Frequency } \\
(\boldsymbol{\%})\end{array}$ & $\begin{array}{c}\text { TDZ-IBA } \\
(\mathbf{m g} / \mathbf{L})\end{array}$ & $\begin{array}{c}\text { Callus } \\
\text { Regeneration } \\
\text { Frequency } \\
(\boldsymbol{\%})\end{array}$ \\
\hline 0.10 & $85.71^{\mathrm{ab}}$ & $0.10+0.10$ & $71.42^{\mathrm{bc}}$ \\
\hline 0.20 & $71.42^{\mathrm{bc}}$ & $0.20+0.10$ & $71.42^{\mathrm{bc}}$ \\
\hline 0.40 & $100.00^{\mathrm{a}}$ & $0.40+0.10$ & $42.85^{\mathrm{d}}$ \\
\hline 0.80 & $42.85^{\mathrm{d}}$ & $0.80+0.10$ & $85.71^{\mathrm{ab}}$ \\
\hline 1.60 & $57.14^{\mathrm{cd}}$ & $1.60+0.10$ & $52.38 \mathrm{c}^{\mathrm{d}}$ \\
\hline
\end{tabular}
different using DMRT test at $P<0.01$

Table 2. Impact of TDZ-IBA concentration on shoot counts from cotyledonay node explant of T. ammi

\begin{tabular}{|c|c|c|c|}
\hline $\begin{array}{c}\text { TDZ } \\
(\mathbf{m g} / \mathbf{L})\end{array}$ & $\begin{array}{c}\text { Shoot } \\
\text { Counts }\end{array}$ & $\begin{array}{c}\text { TDZ-IBA } \\
(\mathbf{m g} / \mathbf{L})\end{array}$ & $\begin{array}{c}\text { Shoot } \\
\text { Counts }\end{array}$ \\
\hline 0.10 & $4.30^{\mathrm{d}}$ & $0.10+0.10$ & $4.00^{\mathrm{d}}$ \\
\hline 0.20 & $19.40^{\mathrm{a}}$ & $0.20+0.10$ & $6.45^{\mathrm{c}}$ \\
\hline 0.40 & $7.29^{\mathrm{bc}}$ & $0.40+0.10$ & $8.25^{\mathrm{b}}$ \\
\hline 0.80 & $7.43^{\mathrm{bc}}$ & $0.80+0.10$ & $8.00^{\mathrm{b}}$ \\
\hline 1.60 & $3.43^{\mathrm{d}}$ & $1.60+0.10$ & $4.00^{\mathrm{d}}$ \\
\hline
\end{tabular}

Means followed by different small letters within columns are sigificantly different using DMRT test at $P<0.05$

Table 3. Impact of TDZ-IBA concentration on shoot length $(\mathrm{cm})$ from cotyledonay node explant of T. ammi

\begin{tabular}{|c|c|c|c|}
\hline $\begin{array}{c}\text { TDZ } \\
(\mathbf{m g} / \mathbf{L})\end{array}$ & $\begin{array}{c}\text { Shoot } \\
\text { Length }(\mathbf{c m})\end{array}$ & $\begin{array}{c}\text { TDZ-IBA } \\
(\mathbf{m g} / \mathbf{L})\end{array}$ & $\begin{array}{c}\text { Shoot } \\
\text { Length }(\mathbf{c m})\end{array}$ \\
\hline 0.10 & $2.08^{\mathrm{c}}$ & $0.10+0.10$ & $1.57^{\mathrm{d}}$ \\
\hline 0.20 & $1.49^{\mathrm{d}}$ & $0.20+0.10$ & $2.74^{\mathrm{a}}$ \\
\hline 0.40 & $1.52^{\mathrm{d}}$ & $0.40+0.10$ & $1.51^{\mathrm{d}}$ \\
\hline 0.80 & $1.50^{\mathrm{d}}$ & $0.80+0.10$ & $1.58^{\mathrm{d}}$ \\
\hline 1.60 & $2.39^{\mathrm{b}}$ & $1.60+0.10$ & $1.04^{\mathrm{e}}$ \\
\hline
\end{tabular}

Means followed by different small letters within columns are sigificantly different using DMRT test at $P<0.01$

The nature/type of explant is highly significant for in vitro shoot induction and proliferation and cotyledonary node explant is very potent explant reported for various important crops (Chaudhary et al., 2007; Kendir et al., 2008; Teymourian et al., 2017). The results revealed the supermacy of cotyledonary node explant and recorded $100.00 \%$. The other studies on this plant also revealed relatively high shoot regeneration using different explants and PGRs. The previous study on T. ammi using seed explant cultured on TDZ-IBA containing medium also yielded high shoot regeneration frequency that was recorded in the range of 77.77-94.44\% (Koca and Aasim, 
2015). Shoot regeneration frequency of $44-100 \%$ was reported in $T$. copticum using cotyledonary node explant (Teymourian et al., 2017). Whereas, 41.1-92.6\% shoot regeneration frequency was reported from zygotic embryos explant of T. ammi (Nomani and Tohidfar, 2021). Callus inducion is an important parameter of in vitro regeneration studies and dependant mainly on type and combination of PGRs along with plant and explant. Results on callus induction frequency (\%) revealed the clear impact of TDZIBA concentration. Results also reveal the variable impact of TDZ or TDZ+IBA concentration on callus induction and recorded $43.85-100 \%$ and $42.85-71.42 \%$ respectively (Table 1). The highest callus induction frequency (100\%) was observed on MS medium enriched with $0.40 \mathrm{mg} / \mathrm{L}$ TDZ. On the other hand, minimum callus induction frequency $(42.85 \%$ ) was recorded on $0.80 \mathrm{mg} / \mathrm{L} \mathrm{TDZ}$ and $0.40 \mathrm{mg} / \mathrm{L}$ TDZ+0.10 mg/L IBA. 13.88-80.00\%. Callus induction in response to different PGRs (combination of auxin and cytokinin) has been reported from hypocotyl explant of $C$. coptimum (Niazian et al., 2017b) cotyledonary node explant of $T$. copticum (Teymourian et al 2017), hypocotyl (Nomani et al., 2021) and zygotic embryos (Nomani and Tohidfar, 2021) of and T. ammi.

The provision of different concentrations of TDZ alone or TDZ-IBA exerted significant impact on shoot counts. Shoot counts on MS medium supplemented with TDZ alone yielded 3.43-19.40 shoots per explants (Table 2). The maximum shoot counts of 19.40 was documented on MS medium supplemented with $0.20 \mathrm{mg} / \mathrm{L}$. However, a sharp decline on shoot counts was recorded thereafter with elevated TDZ concentration and minimum shoot counts was documented on MS medium supplemented with 1.60 $\mathrm{mg} / \mathrm{L}$ TDZ. The negative impact of elevated TDZ concentration on shoot counts have been reported in Hungarian vetch (Sahin-Demirbag et al., 2008) and $T$. ammi (Koca and Aasim, 2015). On the other hand, combination of TDZ-IBA yielded 4.00-8.5 shoots per explant with maximum shoot counts $(8.25)$ were recorded on Ms medium enriched with $0.40 \mathrm{mg} / \mathrm{L}$ TDZ+0.10 mg/L IBA. The study by Teymourian et al (2017) revealed shoot count ranged 1.1-3.5 (shoots per explant) from different culture medium with maximum from medium containing no PGR. Shoot length of in vitro regenerated shoots was also showed the clear impact of TDZ-IBA concentration. Shoot length on MS medium containing different concentration of TDZ ranged 1.49-2.39 cm with longer shoots were attributed to $1.60 \mathrm{mg} / \mathrm{L} \mathrm{TDZ}$ followed by 0.10
mg/L TDZ (Table 3). The general perception about high TDZ concentration is the inhibitory impact on shoot length (Karataş and Aasim 2014). On the other hand, TDZ-IBA containing medium yielded shoot length of 1.04-2.64 cm with longer shoots were attained on MS medium inoculated with $0.40 \mathrm{mg} / \mathrm{L} \mathrm{TDZ}+0.10 \mathrm{mg} / \mathrm{L} \mathrm{IBA}$. The study carried out by Teymourian et al. (2017) revealed shoot length range of $0.5-2.8 \mathrm{~cm}$ with longer shoots from medium containing no PGR.

In vitro regenerated shoots were shifted to MS medium provided with IBA induced relatively low rooting frequency due to induction of hyperhydric shoots in response to TDZ. The induction of hyperhydric shoots due to high concentration of TDZ or cytokinin is reported in most of the plants (Aasim et al., 2011). The study presented by Niazian et al. (2017b) revealed the massive rooting of shoots of $C$. copticum when cultured on $1 / 2$ MS medium having $0.1 \mathrm{mg} / \mathrm{L}$ NAA. Whereas, Nomani et al. (2021) reported root induction of $T$. ammi plantlets inoculated on Ms medium enriched with $0.57 \mu \mathrm{m} / \mathrm{L}$ IAA. The rooted plantlets in this study failed to adapt in the pots containing peat moss. The previous study by Koca and Aasim (2015) on $T$. ammi revealed the successful rooting and adaptation by first done hardening of the shoots on MS medium enrihed with different sucrose cocentration followed by acclimatization of shoots in the growth chamber under controlled conditions. Similarly, high adaptation rate of approximately $60.00 \%$ was reported by Niazian et al. (2017b). Similarly, successful aclimatization have been reported for T. ammi plantlets by (Nomani and Tohidfar, 2021).

Development of in vitro regeneration protocol either through direct or indirect regeneration is highly significant for practicing the biotechnological techniques like genetic transformation, isolation of secondary metabolites. The results of this study reveal the high shoot regeneration and callus induction frequency with high shoot counts and this protocol can be employed for future biotechnological studies.

\section{Conflict of Interest}

Authors have declared no conflict of interest.

\section{Authors' Contributions}

The authors contributed equally.

\section{References}

Aasim M, Sahin-Demirbag N, Khawar KM, Kendir H, Özcan S (2011). Direct Axillary hoot Regeneration From The Mature Seed Explant Of The Hairy Vetch (Vicia villosa Roth)". Archives of Biological Sciences 63(3): 757-762.

Ashraf M, Orooj A (2006). Salt stress effects on growth, ion accumulation and seed oil concentration in an arid zone traditional medicinal plant ajwain (Trachyspermum ammi [L.] Sprague). Journal of Arid Environments 64(2): 209-220.

Bairwa R, Sodha RS, Rajawat BS (2012). Trachyspermum ammi. Pharmacognosy Reviews 6: 56-60.

Chaudhary D, Madanpotra S, Jaiwal R, Saini A, Kumar P, Pawan JK (2007).. Agro bacterium tumefaciens-mediated high frequency genetic transformation of an Indian Cowpea (Vigna unguiculata L. Walp) cultivar and transmission of transgene into progeny. Plant Science 172: 692-700.

Jain N, Sharma V, Ramawat KG (2011). Therapeutic potentials of medicinal plants traditionally used during postpartum period and their molecular targets. Journal of Ecobiotechnology 3: 30.

Jeet K, Devi N, Narender T, Sunil T, Lalit S, Raneev T (2012). Trachyspermum ammi (Ajwain): Comprehensive Review. International Research Journal of Pharmacy 3: 133-138. 
Karataş M, Aasim M (2014). Efficient in vitro regeneration of medicinal aquatic plant water hyssop (Bacopa monnieri L. Pennell). Pakistan Journal of Agricultural Sciences 51(3): 667-672.

Kendir H, Sahin-Demirbag N, Khawar KM, and Aasim M (2008). In vitro plant regeneration from Narbon Vetch (Vicia narbonensis L.) using cotyledonary node explants. African Journal of Biotechnology 7(14): 2491-2494.

Koca A, Aasim M (2015). Establishment of efficient micropropagation system in Bishop's weed (Trachyspermum ammi L) using mature seed explant. Journal of Animal and Plant Sciences 25(2): 478-484.

Kwon PI, Junheon K, Sang-Gil L (2007). Nematicidal activity of plant essential oils and components from ajwain (Trachyspermum ammi), allspice (Pimentadioica) and litsea (Litseacubeba) essential oils against pine wood nematode (Bursaphelenchus xylophilus). Journal of Nematolgy 39: 275-279.

Mathew N, Bhattacharya SM, Perumal V, Muthuswamy K (2008). Antifilarial lead molecules 1solated from Trachyspermum ammi. Molecules 13: 2156-2168.

Moghaddam M, Khaleghi MSN, Ghasemi PA, Mehdizadeh L, Ghaderi Y. (2015). Variation in essential oil composition and antioxidant activity of cumin (Cuminum cyminum L.) fruits during stages of maturity. Industrial Crops and Products 70 : 163-169.

Moosavi SG, Seghatoleslami MJ, Jouyban Z, Ansarinia E, Moosavi SA (2015). Response morphological traits and yield of ajowan (Carum copticum) to water deficit stress and nitrogen fertilizer. Biological Forum 7(1): 293.

Murashige T, Skoog F (1962). A revised medium for rapid growth and bioassays with tobacco tissue cultures. Physiologia Plantarum 15: 473-497.

Niazian M, Noori SAS, Galuszka P, Tohidfar M, Mortazavian SMM (2017b). Genetic stability of regenerated plants via indirect somatic embryogenesis and indirect shoot regeneration of Carum copticum L. Industrial Crops and Products 97: 330-337.

Niazian M, Sadat NSA, Tohidfar M, Mortazavian SMM (2017a). Essential oil yield and agro-morphological traits in some Iranian ecotypes of ajowan (Carum copticum L.). Journal of Essential Oil Bearing Plants 20(4): 1151-1156.

Nomani M, Noori SAS, Tohidfar M, Ramshini H (2021). Regeneration of Trachyspermum ammi L. Sprague ecotypes via indirect somatic embryogenesis using hypocotyl and epicotyl explants. Indian Journal of Experimental Biology 59(04): 263-269.

Nomani M, Tohidfar M (2021). Plant regeneration and transformation of Trachyspermum ammi using Agrobacterium tumefaciens and zygotic embryos. Journal of Genetic Engineering and Biotechnology 19(1): 1-10.

Platel K, Srinivasan K (2001). Studies on the influence of dietary spices on food transit time in experimental rats. Nutrition Research 21: $1309-1314$

Ramaswamy S, Sengottuvelu S, Haja SS, Jaikumar S, Saravanan R, Prasadkumar C, Sivakumar T (2010). Gatroprotective activity of ethanolic extract of Trachyspermum ammi fruit. International Journal of Pharmacy and Biological Sciences 1: 1-15.

Sharifi-Rada M, Sharifi-Radb M, Sharifi-Radc R (2013). Antibacterial activity of Trachyspermum copticum leaves extract against resistant bacteria to antibiotics. Phytoscience 1: 9-12.

Singh VK, Singh S, Singh DK (2003). Pharmacological effects of spices. In: Majumdar DK et al (eds). Recent progress in medicinal plants. Phytochemistry and pharmacology. Houston: Stadium Press, pp. 321-353.

Snedecor GW, Cochran WG, 1967. Statistical Methods. The Iowa State University Press, USA .

Şahin-Demirbag N, Kendir H, Khawar KM, Aasim M (2008). In vitro plant regeneration from Hungarian vetch (Vicia pannonica Crantz) using cotyledonary node explants. Biotechnology \& Biotechnological Equipments 22(4): 929-932.

Teymourian H, Ebrahimi MA, Tohidfar M, Farsaloon N, Zarinpanjeh N (2017). In vitro plantlet regeneration from callus culture of Trachyspermum copticum. Plant Tissue Culture and Biotechnology 27(1): 13-20.

Thangam C, Dhananjayan R (2003). Antiinflammatory potential of the seeds of Carum copticum Linn. Indian Journal of Pharmacology 34: 388-391.

Tripathi L, Tripathi JN (2003). Role of biotechnology in medicinal plants. Tropical Journal of Pharmaceutical Research 2: 243.

Velazhahan R, Vijayanandraj S, Vijayasamundeeswari A, Paranidharan V, Samiyappan R, Iwamoto T (2010). Detoxification of aflatoxins by seed extracts of the medicinal plant, Trachyspermum ammi (L.) Sprague ex Turrill. Structural analysis and biological toxicity of degredation product of aflatoxin G1. Food Control 21: 719-725 